\title{
Sivistysstrategiaa etsimässä
}

\author{
Opetusministeriö julkisti marraskuussa 1993 asiantuntijaryhmän laatiman \\ kansallisen sivistysstrategian (KM 1993: 36). Sittemmin opetusministeriö on \\ tehnyt periaatepäätöksen strategian toteuttamisesta. Sivistysstrategia nostaa \\ esiin kysymyksiä: Ovatko haasteemme ensisijaisesti sivistyksellisiä vai \\ esimerkiksi taloudellisia?
}

Onko talous osa kulttuuria ja sivistystä vai kulttuuri vain osa taloutta? Onko EU:hun liittymisen taloudellisten tekijöiden taustalla myös kulttuurisia tavoitteita?

Strategia-käsitteen käyttöön on kulttuuriyhteyksissä suhtauduttu kriittisesti. Kun pyrkimyksenä on pohdintojen konkretisoiminen hallinnonalan tulossuunnitelmiin, toiminta- ja taloussuunnitelmiin sekä talousarvioihin, suunnittelukielen käyttäminen on välttämätöntä. Kansallisen sivistysstrategian tulevaisuushahmotus perustuu pitkälle systeemiajatteluun, mistä syystä strategia-käsitteen käyttö on luontevaa teknokraattisuuden vaarasta huolimatta.

Strategia-käsitteelle voidaan antaa lähes mikä tahansa sisältö. Se voi olla melko yleinen ja epämääräinen toiminnan linjaus ("yrityksen strategiana on kansainvälistyminen") tai yksityiskohtainen etenemissuunnitelma vaihtoehtoineen ja riskianalyyseineen. Asiantuntijaryhmän strategioita voi luonnehtia suuriksi kehitysaalloiksi, teeseiksi tai julistuksiksi. Sivistysstrategian konkretisoinnin taas pitäisi johtaa toimenpidelinjauksiin ja suunnitelmiin, jolloin sivistysstrategiakin olisi lähempänä tavanomaisemmin ymmärrettyä strategia-käsitteen tulkintaa.

Myös sivistys-käsite on tässä yhteydessä ongelmallinen. Mietinnön mukaan (s. 1) "Sivistys on inhimillisten kykyjen, tietojen, asenteiden ja arvojen ylläpitoa ja kehittämistä." Sivistysstrategiassa olisi näin tulkittuna kysymys osaamisstrategiasta tai jatkuvan oppimisen strategiasta Kansallinen sivistysstrategia pyrkii kuitenkin laajempaan, ottamaan haltuunsa koko kulttuurin. Olisikin tarkoituksenmukaisempaa puhua sivistysstrategian sijaan kulttuuristrategiasta.

Kaikki ihmisen toiminta luo kulttuuria, jonka ydin sivistys on. Samoin kuin strategia-käsitettä on sivistys-käsitettä täten käytetty mietinnössä yleisessä ja väljästi tulkittavassa ja mielikuvia luovassa merkityksessä. Kysymys on käytännössä useasta erillisestä lähestymistavasta. Kulttuurille ja sivistykselle tuskin onkaan tarkoituksenmukaista laatia yhtä kokonaista ja kiinteää strategiaa.

Kansallinen-käsitteen korostaminen voi olla ongelmallista tilanteessa, jossa korostetaan kansainvälisyyttä ja monikulttuurisuutta. On ennakoitu kansallisvaltioiden menettävän merkitystään. Mikäli kykenemme terveeseen itsekkyyteen ja aitoon epäitsekkyyteen, kansallisen korostamisella on uudenlainen vuorovaikutusta korostava sisältö. Kyseessä on sivistyshaaste.

\section{Tulevaisuusajattelu}

Kulttuuri ja sivistys on itsestäänselvästi pitkän aikavälin kysymys. Samoin sivistystoimintojen kuten kasvatuksen ja koulutuksen vaikutukset ovat ihmisen elinkaaren pituisia. Opetusministeriön hallinnonalan kehittämisessä pitkän aikavälin huomioon ottaminen on välttämättömyys. 
Opetusministeriössä on tehty pitkän aikavälin suunnittelua vakiintuneesti. Analyyttisin ja perusteellisin tulevaisuuden ennakointi on liittynyt koulutustarpeiden arviointiin, mitä etenkin Koulutussuunnittelun neuvottelukunta on tehnyt (KM 1983: , 1988: 28, 1990: 49 ja 1994: 1). Ennakointi on koskenut painotetusti koulutusmääriä. Lähestymistapa on ollut trendipainotteinen. Koulutuksen laatua, rakenteita ja sisältöjä käsittelevä visiointi on ollut vähäisempää ja satunnaisempaa. Pitkän aikavälin ennakoinneista esimerkkejä ovat Tulevaisuusbarometri 1993 (Mannermaa \& Mäkelä 1993) ja suurten kehitysaaltojen tarkastelu (Mäkelä 1993).

Siinä missä trendit luotaavat tulevaisuutta menneestä, visiot tuovat ideoita ja tavoitteita tulevaisuudesta tähän päivään. Opetusministeriössä visiotyö käynnistyi vuonna 1991 (Visioryhmän muistio 1992).

Visioryhmällä oli järjestelmällinen tarkastelumalli. Visioryhmä jäsensi työnsä kolmeen vaiheeseen: 1) toimintaympäristön muutoksen arviointi; 2) väestön kulttuuri- ja sivistystarpeiden tunnistaminen; ja 3) sivistystoimen kehittämisstrategia. Toimintaympäristön muutokset kuvattiin suurilla kehitysaalloilla eli megatrendeillä. Väestön sivistys- ja kulttuuritarpeiden tunnistaminen jäi keskeneräiseksi siten, että työstä ei ollut johdettavissa sivistystoimen kehittämisstrategioita. Syynä epäonnistumiseen oli toisaalta työryhmän nykyiselle hallintokulttuurille tyypillinen erittäin lyhytjänteinen toimintatapa ja toisaalta tarjonta-ajattelun korostuminen tarve- tai kysyntäajattelun sijaan (vrt. koulutuksen tarjonta vs. koulutuksen tarve). Kehittämisstrategioita ja ideoita on toki syntynyt visiotyöstä riippumatta, mistä syystä sinänsä hyviä ehdotuksia muistioon (1992: 25) sisältyykin.

Visioryhmän työ loi joka tapauksessa perustan yksinkertaisemmalle suurten kehitysaaltojen tarkastelutavalle, jolla kansallinen sivistysstrategia voitiin laatia taas muutamassa kuukaudessa.

\section{Avainstrategiat}

Kansallinen sivistysstrategia koostuu kymmenestä avainstrategiasta (A - J). Avainstrategiat ovat suuria kehitysaaltoja tai päänäkökulmia, joiden kautta sivistystä pyritään jäsentämään. Avainstrategiat nostavat esille ne näkökulmat, joihin tässä ajassa ja tämän hetken käsityksen mukaan tulisi tarttua. Avainstrategiat voidaan jakaa neljään ryhmää: päämäärästrategioihin, toimintaympäristöstrategioihin, sivistystoimintostrategioihin sekä toimintamallistrategioihin.

Päämäärästrategiat ovat selkeästi arvoihin liittyviä. Näitä ovat Inhimillisen kasvun ja vastuun strategia (13), Monikulttuurisuuden strategia (C) ja Kestävän kehityksen strategia (1». Strategioissa on kysymys uusista tai vanhoista hyväksi ymmärretyistä arvovalinnoista. Esimerkiksi inhimillisen kasvun strategia nostaa esiin toisaalta viime vuosina korostetut ekologiset arvot ja toisaalta perinteisemmät humanistiset arvot.

Toimintaympäristöstrategioihin lukeutuvat Hallitun ja monipuolisen kansainvälisyyden strategia (E) ja Työkulttuuristrategia $(F)$. Jälkimmäisessä on kysymys meneillään olevasta työn ja työelämän suureen murrokseen vastaamisesta. Tähän ryhmään voisi sisältyä myös vapaa-aikastrategia.

Sivistystoimintostrategioita ovat Sivistyksellisten perusoikeuksien strategia (A), Jatkuvan oppimisen strategia (G) ja Innovaatiostrategia $(H)$. Tähän strategiaklusteriin olisi lisättävissä nuorisostrategia, liikuntastrategia sekä luovan toiminnan ja taiteen strategia.

Toimintamallistrategioita ovat Kansalaistoiminta sivistysyhteiskunnan voimavarana (I) ja Sivistyksen vuorovaikutus- ja verkostostrategia (J). Nämä ovat uusia niin koko yhteiskunnan kuin kulttuuritoimintojenkin toimintamalleja. 
Mietinnössä kukin avainstrategia on kuvattu esittämällä pääpiirteittäin strategian tavoitteet ja sisältö sekä esimerkinomaisesti toimenpide-ehdotuksia. Näin strategiat avautuvat eräänlaisina luonnoksina, joissa on tilaa uusille innovaatioille.

\section{Kohti jatkuvaa oppimista}

Kansallisen sivistysstrategian ei tarvitse jäädä pelkäksi julistukseksi. Etenkin verkostokulttuuriin siirtyminen ja työn murros ovat edessämme suuria muutoksia, joihin koulutuksen tulisi kyetä vastaamaan. Visiona on jatkuvan oppimisen järjestelmä, josta olemme vielä kaukana. jatkuvan oppimisen strategia voisikin olla se päänäkökulma, josta kansallinen sivistysstrategia voidaan konkretisoida.

Kulttuurinen ja taloudellinen toiminta verkottuu maailmanlaajuisesti. Tällä kehityssuunnalla on sinänsä pitkät perinteet. Tiedon kulun nopeutuminen reaaliaikaiseksi on muuttamassa ratkaisevasti toimintamalleja niin työssä kuin vapaa-aikana. Uusi tietotekniikka on merkittävästi nopeuttanut ja järkevöittänyt myös tavaraliikennettä. Kuljetusten optimointi eli logistiikka ei ole vain talouden vaan ennen muuta avaintekijä kestävän kehityksen tavoitteen kannalta.

Työn murroksen tai verkottumisen piirteitä ovat muun muassa verkosto- eli etätyön lisääntyminen, yksilöllisen ydinosaamisen korostuminen, yksilölliset työpanokset ja työn ajoitukset, yksilöllisen vastuun ja oma-aloitteisuuden korostuminen, kansainvälistymisen jatkuminen ja kansalais- tai vapaaehtoistyön lisääntyminen. Samaa osaamista joku voi hyödyntää palkkatyössä, toinen yrittäjänä, kolmas vapaaehtoistyössä ja neljäs vapaa-ajan harrasteena. Uuteen monisyiseen työkulttuuriin siirtyminen on suuri haaste koulutukselle.

Myös koulutuksen on muunnuttava verkostorakenteiseksi. Tämä tarkoittaa oppimiskeskusten erikoistumista ja lisääntyvää yhteistyötä. jokaisella verkostossa toimivalla tulee olla ydinosaamista. Tutkintokorosteisesta koulutuksesta on siirryttävä osaamis- tai kvalifikaatiokeskeiseen koulutukseen, mikä edellyttää koulutuksen modulointia. Koulutuksen rajojen kuten yleissivistävä koulutus vs. ammatillinen koulutus on murruttava. Yhtäältä yleissivistäviäkin taitoja on hankittava koko elinkaaren ajan, yhtäältä vastuuta on annettava jo lapsille. Luova toiminta on otettava koulutuksessa sekä välineeksi että sisällöksi. Oppimisverkosto on ymmärrettävä selvästi laajemmaksi kuin vain perinteiset koulutusinstituutiot. Etenkin sähköisellä medialla ja uudistuvalla kirjastolla (mediastolla) on mittavat mahdollisuudet. Myös kotien kasvatusrooli tulisi olla jatkuvan tutkimuksen ja keskustelun alaisena. Kansallisessa koulutusstrategia tulisi hahmottaa verkostostrategiana, jossa määriteltäisiin eri instituutioiden rooli. Kysymys ei ole niinkään eri tahojen velvollisuuksista vaan mahdollisuuksista.

\section{Sivistysstrategian kehittäminen}

Kansallisen sivistysstrategian kehittämiseksi opetusministeriö on ryhtynyt jo valmisteleviin toimiin. Tavoitteena on analyysin syventäminen - sekä visioryhmän työ että sivistysstrategia on koettu perusteluiltaan osin ohueksi ja jäsentymättömäksi. Sivistyksen tulevaisuuden tutkimushankkeella pyritään strategianmuodostuksen tueksi saamaan tutkimuksellista tietoa. Eurooppa-skenaarioiden laatimisella taas on tarkoitus hyödyntää sekä tutkimustietoa että muiden asiantuntijoiden tietämystä. Edelleen sivistys- tai kulttuuriskenaariot on kytkettävä maassa tekeillä oleviin lukuisiin muihin tulevaisuus-hankkeisiin.

Tulevaisuusstrategioiden laatimisessa on useita vaihtoehtoisia tai toisiaan täydentäviä strategiavaihtoehtoja (ks. Mäkelä 1994). Sivistysstrategian syventämiseksi soveltuu esimerkiksi visioryhmän käyttämä jäsennys: Toimintaympäristövisioiden ja skenaarioiden perusteella laaditaan arviot kansalaisten sivistystarpeista. Näihin liittyvät kiinteästi kansalaisten sivistykselliset oikeudet ja velvollisuudet. Kun aidot tarpeet tunnetaan, strategioiden laatiminen sivistystoimintojen ja muiden sivistyksen edellytysten luomiseksi on yksinkertaista. 
Suomessa on viime vuosina laadittu useita tulevaisuutta makrotasolla luotaavia raportteja. Maanantaiseura julkaisi yhdeksän tulevaisuuskuva-raporttia (1992-1993). Valtioneuvosto antoi eduskunnalle selonteon pitkän aikavälin tulevaisuudesta (1993), josta eduskunnan tulevaisuusvaliokunta laatii mietinnön. Iltalehti julkaisi asiantuntijaryhmän laatiman Suomen strategian - holhousvaltiosta aloite ja yrittäjävaltioksi (1993). Lisäksi on laadittu sektorikohtaisia strategioita sivistysstrategian tapaan kuten Kansallinen teollissuustrategia (1993). Laadittavana on muun muassa kansallinen tietotekniikkastrategia.

Visioiden ja strategioiden ongelma on siinä, että niihin ei sitouduta. Strategiat pikemminkin kilpailevat keskenään kuin pyrkisivät luovaan vuorovaikutukseen. Strategiat eivät näin myöskään yllä kansalaiskeskustelun piiriin. Toivoa on asetettava esimerkiksi kansanedustajiin, joista ainakin osa on kiinnostunut niin tulevaisuus- kuin kulttuurikysymyksistä. Eduskunta- ja muissa vaaleissa kysymys tulisi asettua siten, että kansalaiset voisivat valita vaihtoehtoisista tulevaisuuskuvista, jotka käsittelisivät esimerkiksi yhdyskuntarakenteita, elämäntapoja tai kulttuuritoimintoja.

Harva kansanedustaja tai edustajaehdokas kuitenkaan kykenee tai haluaa esittämään minkäänlaista visiota.

\section{LÄHTEET}

Kansallinen teollisuusstrategia. Kauppa-ja teollisuusministeriön julkaisuja 1/1993.

Komiteanmietintö 1983. Koulutussuunnittelun neuvottelukunnan mietintö. Komiteanmietintö 1983: 60.

Komiteanmietintö 1988. Väestön koulutus 2000. Koulutussuunnittelun neuvottelukunta. Komiteanmietintö 1988.- 28.

Komiteanmietintö 1990. Kehittyvä koulutus. Koulutussuunnittelun neuvottelukunta. Komiteanmietintö 1990.- 49.

Komiteanmietintö 1993. Kansallinen sivistysstrategia. Opetusministeriön asiantuntijaryhmän ehdotus sivistyspolitiikan perustaksi. Komiteanmietintö 1993: 36

Komiteanmietintö 1994. Kansallinen koulutusstrategia.

Koulutussuunnittelun neuvottelukunnan mietintö. Komiteanmietintö 1994:1.

Maanantaiseuran tulevaisuuskuvia julkaisut 1-9. Painatuskeskus, Helsinki 1992-1993.

Mannermaa, M.. \& Mäkelä, K. 1994. Tulevaisuusbarometri 1993. Yhteiskuntakehityksen ja koulutuksen tulevaisuudennäkymiä vuoteen 2017. Opetusministeriön suunnittelusihteeristön keskustelumuistioita 21.

Mäkelä, K. 1994. Miten laatia tulevaisuusstrategia. Teoksessa Sivistys 2017, toimittanut L. Lehtisalo. SITRA:n julkaisusarja nro 132. WSOY, s 269-291.

Mäkelä, K. Suuret kehitysaallot ja koulutustarpeet. Mitä sosiaali- ja terveydenhuolto voi odottaa tulevaisuudelta. Dialogi 7/1993, s. 34-36

Sivistys-Suomi 2010. Opetusministeriön visioryhmän muistio. Opetusministeriön työryhmien muistioita 1992: 25.

Suomen strategia -holhousvaltiosta aloite- ja yrittäjävaltioksi. Iltalehti 5.6.1993.

Suomen tulevaisuus ja vaihtoehdot. Valtioneuvoston selonteko eduskunnalle pitkän aikavälin tulevaisuudesta 27.10.1993. Valtioneuvoston kanslian julkaisusarja 1993/1. 